\title{
Penggunaan Media Animasi Berbasis Macromedia Flash untuk Meningkatkan Hasil Belajar Siswa pada Konsep Materi Sistem Peredaran Darah Manusia (Using Macromedia Flash Based Animation to Improve Students' Learning Outcomes in the Concept of Human Circulatory System)
}

\author{
Risya Pramana Situmorang ${ }^{1 *}$, Elisabeth Perti Andayani ${ }^{2}$ \\ ${ }^{1}$ Program Studi Pendidikan Biologi Fakultas Biologi Universitas Kristen Satya Wacana, J1.. Diponegoro No. 42-60, Kota Salatiga, Jawa \\ Tengah, Indonesia \\ ${ }^{2}$ SMP Kristen 4 Salatiga, Jl. Tentara Pelajar No.4, Mangunsari, Sidomukti, Kota Salatiga, Jawa Tengah, Indonesia \\ *Corresponding author: pramana.risya@staff.uksw.edu
}

Received: 28 December 2018 - Accepted: 29 March 2019 - Published: 30 March 2019

\begin{abstract}
This research aims to improve cognitive, affective and psychomotor learning outcomes through using animation based on macromedia flash. The subjects of classroom action research were 20 students, 11 male students and 9 female students from class VIII Christian Middle School 4 Salatiga. The study was conducted for 2 months in the 2017/2018 school year with 4 meetings. Measurements on cognitive learning outcomes, used instruments in the form of learning outcomes tests with 25 items, affective and psychomotor domains using questionnaire and observation sheets. Data processing and analysis used is description analysis. The percentage gain in the pre-cycle is $25 \%$ and the percentage of student learning completeness is obtained in the first cycle with a percentage of $52.9 \%$. Furthermore cognitive learning outcomes also increased in the second cycle to $82.3 \%$. The increase in the percentage of students 'completeness with an average of $53.4 \%$ indicates that there is a change and an increase in students' cognitive learning outcomes from the pre-cycle, cycle I and cycle IIAffective learning outcomes in the first cycle had a achievement of $55 \%$, the acquisition of affective aspects in the first cycle still had not achieved the expected completeness, namely the standard score of $70 \%$. However, in the second cycle the affective aspect achieved a percentage score of $78 \%$. While the psychomotor aspects in the first cycle were $53 \%$, increasing up to $75 \%$ in the second cycle with completeness of $\geq 75 \%$.
\end{abstract}

Keywords animation, cognitive, affective, psychomotor media

\begin{abstract}
ABSTRAK Penelitian ini bertujuan untuk mengetahui peningkatan hasil belajar kognitif, afektif, dan psikomotor melalui penggunaan media animasi berbasis macromedia flash. Subjek penelitian tindakan kelas (PTK) ini berjumlah 20 orang, dengan jumlah siswa laki-laki 11 orang dan siswa perempuan 9 orang yang berasal dari siswa kelas VIII SMP Kristen 4 Salatiga. Penelitian dilakukan selama 2 bulan pada tahun ajaran 2017/2018 sebanyak 4 kali pertemuan tatap muka. Pengukuran terhadap hasil belajar kognitif, digunakan instrumen berupa tes hasil belajar dengan 25 butir soal, ranah afektif dan psikomotorik menggunakan angket dan lembar observasi. Pengolahan dan analisis data yang digunakan adalah analisis deskripsi. Perolehan persentase pada pra siklus sebesar 25\% dan perolehan persentase ketuntasan belajar siswa pada siklus I dengan persentase $52.9 \%$. Selanjutnya hasil belajar kognitif juga mengalami kenaikan pada siklus II menjadi $82.3 \%$. Kenaikan persentase ketuntasan siswa dengan rata-rata 53,4\% menunjukkan bahwa terjadi perubahan dan peningkatan hasil belajar kognitif siswa dari pra siklus, siklus I dan siklus II. Aspek afektif siklus I memiliki nilai rata-rata yaitu 55\%, perolehan aspek afektif pada siklus I masih belum mencapai ketuntasan yang diharapkan yaitu sebesar 70\%. Pada siklus II aspek afektif mencapai hasil sebesar 78\%. Sementara aspek psikomotorik siswa pada siklus I yaitu 53\% mengalami peningkatan hingga $75 \%$ pada siklus II dengan ketuntasan yaitu $\geq 75 \%$.
\end{abstract}

Kata kunci media animasi, kognitif, afektif, psikomotorik

\section{PENDAHULUAN}

Mata pelajaran IPA merupakan bidang keilmuan yang mempelajari mengenai fenomena dan gejala alam. Pentingnya keterlibatan siswa melalui aktivitas langsung dalam proses pengamatan dari metode ilmiah yang diterapkan. Proses untuk mempelajari objek sains membutuhkan aktivitas yang berorientasi pada keterlibatan langsung melalui pengamatan. Aplikasi dari konsep yang dipelajari dapat memberikan pemahaman yang lebih komprehensif kepada siswa sehingga IPA tidak bersifat abstrak atau sekedar teori pada buku teks. Pentingnya pembelajaran IPA yang mengarahkan pada pengalaman nyata membuktikan membutuhkan suatu pembuktian melalui data dan fakta pada setiap fenomena yang diamati (Surani, 2015; Wulandari, 2017). 
Perencanaan pembelajaran berkaitan dengan cara guru mempersiapkan proses pembelajaran yang aktif bagi siswa. Aktivitas siswa selama pembelajaran merupakan salah satu faktor dalam pembelajaran yang berpusat pada siswa. Aktivitas siswa dapat dibangun melalui penggunaan media pembelajaran yang menarik. Perancangan media pembelajaran yang disesuaikan konsep materi penting dilakukan agar pemahaman siswa mengenai konsep materi dapat dilakukan secara mendalam. Mahdjoubi \& ARahman (2012) menjelaskan bahwa penyajian materi secara visual dapat mempengaruhi jumlah informasi yang tersimpan serta dapat diproses memori secara maksimal sehingga dapat meningkatkan hasil belajar.

Pelaksanaan pembelajaran IPA di SMP Kristen 4 Salatiga sering menemui permasalahan yang berkaitan dengan kurangnya antusias siswa, sikap dan prestasi belajar. Hal ini terlihat dari observasi kelas, siswa cenderung kurang bersemangat dalam belajar dan banyak diantaranya yang menyatakan bahwa belajar IPA itu sulit. Jika ditinjau dari kemampuan kognitif siswa, berdasarkan ulangan harian materi biologi kelas VIIIA SMP Kristen 4 Salatiga, memiliki persentase ketuntasan yang cukup rendah pada materi sistem peredaran darah pada manusia setiap tahun ajaran dengan rata-rata 20,45\% siswa yang tuntas KKM. Menurut guru, materi IPA yang dijelaskan selama ini hanya bersifat informatif saja sehingga pemahaman siswa hanya sebatas pemahaman teoritik. Kriteria ketuntasan minimal pada mata pelajaran IPA yaitu 75. Rata-rata ketuntasan siswa adalah $25 \%$, yang diperoleh dari hasil ulangan harian mata pelajaran IPA semester 1 tahun ajaran 2017/2018. Di sisi yang lain, sarana dan prasarana di kelas maupun laboratorium yang tersedia di sekolah tersebut cukup baik. Artinya pelaksanaan pembelajaran berbasis multimedia dapat dilakukan di kelas. Selain itu, kegiatan praktikum juga dapat dilakukan di laboratorium meskipun keberadaan bahan-bahan kimia yang masih terbatas. Berdasarkan hasil observasi siswa, diperoleh hanya $15 \%$ saja siswa yang memiliki sikap disiplin dan tanggung jawab di sekolah maupun kelas. Hal ini terlihat dari tanggung jawab siswa dalam mengerjakan tugas yang diberikan oleh guru.

Capaian pembelajaran IPA di tingkat Sekolah Menengah Pertama (SMP) menuntut siswa memiliki pola penalaran yang sifatnya mendasar. Selanjutnya siswa dituntut untuk mengingat, memahami dan mengaplikasikan teori dan hukum-hukum dalam mata pelajaran IPA. Konsep IPA yang berkaitan dengan proses visualisasi, penyajian gambar dan video membutuhkan suatu tugas bagi guru untuk dapat memfasilitasi siswa untuk belajar IPA dengan mudah. Guru harus mendorong siswa agar dapat membantu siswa memahami materi dengan pemahaman mereka sendiri sehingga pembelajaran dapat dimaknai secara utuh. Penyajian IPA dapat dilakukan tahap demi tahap guna merepresentasikan materi-materi yang dianggap kompleks melalui aktivitas permodelan, simulasi bahan film animasi (Barak \& Dori, 2011). Oleh sebab itu, agar dapat memfasilitasi siswa dalam penyampaian materi IPA secara menarik dan mudah dipahami salah satunya menggunakan media animasi.

Media animasi dapat membantu penyampaian materi IPA yang bersifat abstrak melalui penjelasan gambar bergerak dan suara. Penggunaan media animasi dirancang melalui macromedia flash karena dapat menyajikan materi presentasi dengan kemampuan ilustrasi yang cukup tinggi (Kusuma et al., 2015). Penggunaan media animasi pada pelajaran IPA diharapkan dapat menyajikan konsep, prinsip dan hukum IPA secara praktis. Pada akhirnya siswa akan merasa lebih mudah memahami IPA ketika menggunakan media pembelajaran yang menarik khususnya melalui media animasi.

Muehrer, Jenson, \& Friedberg (2012) menjelaskan bahwa interaksi yang dibangun di kelas menjadi salah satu faktor dalam capaian pembelajaran yang efektif. Siswa yang terlibat secara langsung dapat meningkatkan antusiasme siswa dalam proses pembelajaran. Selain itu, guru juga dapat menjelaskan materi pembelajaran melalui video animasi sehingga materi pelajaran yang disampaikan tidak bersifat abstrak. Mnguni (2014) menegaskan bahwa proses visualisasi yang dilakukan bagi siswa dapat meningkatkan proses kognitif siswa. Pemanfaatan macromedia flash melalui media animasi diharapkan dapat memperbaiki motivasi serta cara berpikir siswa sehingga proses belajar menjadi lebih optimal.

Trindade (2005) menjelaskan beberapa kelebihan dari media ajar berbasis virtual yaitu dapat menyajikan objek sains dari berbagai sudut pandang, dapat memberikan ilustrasi mengenai berbagai aspek fenomena alam, memberi visualisasi mengenai objek terkecil atau mikroskopis, menyajikan fenomena alam yang bersifat logis serta sesuai dengan konsep yang sebenarnya dan memberikan kesempatan kepada siswa untuk melakukan simulasi atau demonstrasi. Proses visualisasi yang diberikan diharapkan dapat memperbaiki pemahaman siswa tentang sains sehingga dapat meningkatkan hasil belajar kognitif siswa.

Berbagai penelitian telah melaporkan bahwa media animasi berbasis macromedia flash sudah banyak digunakan untuk meningkatkan hasil belajar dan membuktikan bahwa media animasi dapat meningkatkan hasil belajar kognitif, afektif dan psikomotorik siswa dibanding media konvensional (Agustina et al., 2018; Gustina et al., 2016; Sukiyasa, 2013). Media konvensional merupakan media sederhana yang umum digunakan guru dan kurang berpotensi dalam menciptakan interaksi dua arah antara guru dan siswa (Ismunandar, 2017). Penggunaan media animasi yang dikembangkan menggunakan macromedia flash dipandang sangat penting mengingat materi pembelajaran biologi dapat disampaikan secara konkrit sehingga dapat mengurangi kesulitan siswa terhadap materi yang bersifat abstrak. Selain itu, masih belum banyaknya penelitian yang dilakukan menggunakan media animasi untuk meningkatkan ranah kognitif, afektif, dan psikomotorik.

Penggunaan media animasi dipandang sangat penting mengingat isi materi yang kompleks pada sistem peredaran darah, misalnya mengenai komponen-komponen darah, tekanan darah, organ yang terlibat dalam peredaran darah manusia dan mekanisme peredaran darah. Melalui penggunaan media animasi, materi sistem peredaran darah pada manusia dapat dilakukan penyederhanaan konsep sehingga siswa dapat mengamati secara langsung komponen-komponen darah, konsep tekanan darah dan mekanisme aliran darah. Oleh karena itu, melalui penggunaan media animasi siswa dapat lebih mudah memahami materi pelajaran yang diberikan guru sekaligus 
konsep penting pada materi sistem peredaran darah manusia dapat tersampaikan.

\section{METODE}

Penelitian ini merupakan Penelitian Tindakan Kelas (PTK yang dilakukan untuk mengatasi berbagai permasalahan yang ditemukan di kelas. Penelitian ini memiliki fokus dalam peningkatan kualitas proses pembelajaran yang terjadi di kelas menjadi pembelajaran yang efektif. Pelaksanaan PTK dilaksanakan dengan latar belakang kasuistik yang memperhatikan kondisi, keadaan, dan situasi di kelas, yang selanjutnya dilakukan pemecahan terhadaptiap masalah yang ditemukan guna meningkatkan kualitas pembelajaran (Saminanto, 2010). Penelitian tindakan kelas yang dilakukan terbagi dalam 2 siklus penelitian. Tiap siklus dilaksanakan 2 kali pertemuan yang meluputi kegiatan perencanaan, pelaksanaan, pengamatan dan refleksi. Pelaksanaan siklus 1 dan siklus 2 dengan sub topik darah, alat peredaran darah dan mekanisme peredaran darah merupakan rangkaian yang saling berkaitan dengan menggunakan model Kemmis dan Mc Taggart (Paidi, 2010). Penelitian tindakan kelas menurut Kemmis dan Mc. Taggart menyatakan jika dalam satu siklus PTK terdiri dari 4 langkah pokok yaitu rencana, tindakan, pengamatan dan refleksi.

Subjek penelitian tindakan kelas (PTK) ini berjumlah 20 orang, dengan jumlah siswa laki-laki 11 orang dan siswa perempuan 9 orang yang berasal dari siswa kelas VIII SMP Kristen 4 Salatiga. Penelitian dilakukan selama 2 bulan pada tahun ajaran 2017/2018 sebanyak 4 kali pertemuan tatap muka. Penelitian ini menggunakan hasil belajar siswa yang meliputi 3 ranah yaitu kognitif, afektif dan psikomotorik sebagai data penelitian. Pelaksanaan siklus pada Penelitian Tindakan Kelas ini dilakukan secara berulang sampai permasalahan dianggap sudah berhasil diselesaikan. Indikator keberhasilan yang ditetapkan di akhir siklus yaitu: 1) terjadi peningkatan hasil belajar kognitif siswa yang memperoleh nilai di atas KKM hingga $75 \%$, 2) terjadi peningkatan aspek afektif siswa setelah menggunakan model media animasi sebesar $70 \%$ dengan kategori baik 3) terjadi peningkatan aspek psikomotorik siswa sebanyak $70 \%$ dengan kategori baik.

Perolehan data 3 teknik pengumpulan data yaitu: observasi yaitu dengan mengamati aspek psikomotorik siwa pada saat pembelajaran berlangsung dari tahap awal kegiatan hingga tahap akhir kegiatan, tes yaitu memberikan bentuk soal pilihan ganda dan essai dengan jumlah item soal 25 butir. Tes dilakukan dengan cara pretest dan posttest mengenai materi pembelajaran struktur dan fungsi tumbuhan. Angket sikap diberikan kepada peserta didik di akhir pembelajaran yang bertujuan untuk mengetahui respon siswa melalui pernyataan angket tentang sikap siswa.

Data kuantitatif ini dianalisis menggunakan rumus persamaan presentase keterlaksanaan sebagai berikut:

$$
P=\frac{f}{N} \times 100 \%
$$

Keterangan:

$\mathrm{P}=$ Nilai yang dinyatakan dalam persentase $; \mathrm{F}=$ Frekuensi yang sedang dicapai presentasenya; $\mathrm{N}=$ Jumlah frekuensi
Untuk mengetahui kriteria hasil data instrumen penelitian yang dilakukan maka data yang mula-mula berupa skor di ubah menjadi data kualitatif (data interval) dengan skala lima. Acuan pengubah skor menjadi skala lima tersebut sebagai berikut:

Tabel 1. Kriteria Aspek Afektif dan Psikomotorik (Anwar et al., 2017)

\begin{tabular}{cc}
\hline Interval Skor & Kategori \\
\hline $75-100$ & Sangat baik \\
$65-74$ & Baik \\
$55-64$ & Cukup \\
$0-55$ & Kurang \\
\hline
\end{tabular}

\section{HASIL DAN PEMBAHASAN}

Penelitian tindakan kelas dengan penggunaan media animasi berbasis macromedia flash dirancang untuk meningkatkkan hasil belajar kognitif, afektif dan psikomotorik siswa kelas VIII SMP Kristen 4 Salatiga pada materi sistem pernapasan manusia. Hasil penelitian menunjukkan peningkatan hasil belajar kognitif, afektif dan psikomotorik siswa yang diterapkan dari siklus pertama hingga siklus kedua dengan jumlah pertemuan dilakukan sebanyak dua kali tiap pertemuan. Pada akhir siklus kedua diperoleh keberhasilan pencapaian semua indikator. Hasil penelitian setiap siklus dijabarkan sebagai berikut.

\section{Pra siklus}

Berdasarkan hasil observasi dan wawancara yang dilakukan peneliti, guru sudah menggunakan media pembelajaran yang tersedia di kelas, misalnya papan tulis dan charta. Namun guru masih belum mengoptimalkan beberapa fasilitas yang sudah tersedia di kelas. Akibatnya banyak siswa yang merasa kurang tertarik ketika belajar IPA. Hasil belajar IPA pun menjadi kurang optimal dalam pencapaiannya. Hal ini ditunjukkan dengan nilai ulangan harian kelas VII pada materi sebelumnya dengan pencapaian siswa tuntas sebesar $25 \%$ dengan nilai KKM 75. Pada pra siklus diperoleh hasil belajar kognitif seperti pada tabel 2.

Tabel 2. Hasil Belajar Kognitif Siklus I

\begin{tabular}{lc}
\hline \multicolumn{1}{c}{ Deskripsi Hasil Belajar Kognitif } & Siklus I \\
\hline Nilai rata-rata & 52,5 \\
Nilai maksimal & 72 \\
Nilai minimal & 20 \\
Standar deviasi & 17,35 \\
Persentase ketuntasan belajar & $25,3 \%$ \\
Persentase ketidaktuntasan belajar & $74,7 \%$ \\
\hline
\end{tabular}

Ditinjau dari aspek afektif, guru hanya melakukan evaluasi terhadap sikap berdasarkan aspek disiplin dan bertanggung jawab. Hasil yang diperoleh yaitu hanya 40\% siswa yang bertanggung jawab untuk mengerjakan tugas yang diberikan oleh guru, dan $20 \%$ siswa yang disiplin dalam mengikuti kegiatan pembelajaran. Sementara aspek psikomotorik siswa guru berhasil mengevaluasi kemampuan menggunakan alat dan sikap kerja siswa dengan persentase $50 \%$ siswa yang sudah mampu dalam menggunakan alat-alat laboratorium dan memiliki sikap 
kerja yang sesuai dengan kerja ilmiah. Kemampuan membaca gambar atau symbol juga masih lemah dengan capaian persentase $20 \%$ siswa yang dapat membaca simbol atau gambar yang diberikan oleh guru.

\section{Siklus I}

Tahap perencanaan pada penelitian tindakan kelas yang telah dilaksanakan meliputi sebagai berikut: 1) Penyiapan media animasi pembelajaran menggunakan software macromedia flash, 2) Uji validasi media animasi berbasis macromedia flash kepada praktisi, 3) membuat rencana pelaksanaan pembelajaran, 4) Penyusunan instrumen tes untuk mengukur peningkatan hasil belajar kognitif, afektif dan psikomotorik siswa. Pada siklus I diperoleh hasil belajar seperti pada tabel 2 .

Tabel 2. Hasil Belajar Kognitif Siklus I

\begin{tabular}{lc}
\hline \multicolumn{1}{c}{ Deskripsi Hasil Belajar Kognitif } & Siklus I \\
\hline Nilai rata-rata & 71,38 \\
Nilai maksimal & 90 \\
Nilai minimal & 42 \\
Standar deviasi & 16,82 \\
Persentase ketuntasan belajar & $52,9 \%$ \\
Persentase ketidaktuntasan belajar & $47,1 \%$ \\
\hline
\end{tabular}

Berdasarkan perolehan hasil belajar didapatkan persentase ketuntasan belajar IPA sebesar 47,1\%. Perolehan persentase masih belum mencapai dengan tingkat ketuntasan belajar yaitu $>80 \%$. Nilai rata-rata siswa pada siklus I yaitu 71,38 yang berarti masih belum sesuai dengan batas tuntas KKM yang seharusnya 75. Oleh karena itu, perlu ditindaklanjuti dengan kegiatan refleksi dan tindakan pada siklus II. Penilaian aspek afektif siswa dilakukan melalui teknik observasi. Dari lima aspek afektif yang berkaitan dengan sikap siswa yang diamati, didapatkan perolehan angka sebagai bahan perbandingan pada siklus berikutnya. Hasil tersebut dapat dilihat pada tabel 3 dengan persentase rata-rata afektif belajar siswa sebesar $55 \%$.

Tabel 3. Data Afektif Siswa Siklus I

\begin{tabular}{lcc}
\hline Data Aspek Afektif Siswa & Jumlah Siswa & $\begin{array}{c}\text { Persentase } \\
(\%)\end{array}$ \\
\hline Disiplin & 9 & 53 \\
Bertanggung jawab & 8 & 47 \\
Teliti & 7 & 41 \\
Menghargai & 12 & 71 \\
Bekerja sama & 11 & 65 \\
Rata-rata persentase ketuntasan & & 55 \\
\hline
\end{tabular}

Perolehan aspek psikomotorik siswa didapatkan persentase ketuntasan belajar IPA sebesar 53\%. Perolehan persentase masih belum mencapai dengan tingkat ketuntasan belajar yaitu $>70 \%$. Dari ketiga aspek psikomotorik yang berkaitan dengan keterampilan yang diamati, didapatkan perolehan angka sebagai bahan perbandingan pada siklus berikutnya.

Tabel 4. Data Psikomotorik Siswa Siklus I

\begin{tabular}{lcc}
\hline \multicolumn{1}{c}{ Data Hasil Psikomotorik } & $\begin{array}{c}\text { Jumlah } \\
\text { Siswa }\end{array}$ & $\begin{array}{c}\text { Persentase } \\
(\%)\end{array}$ \\
\hline $\begin{array}{l}\text { Kemampuan menggunakan alat dan } \\
\text { sikap kerja }\end{array}$ & 11 & 65 \\
\hline
\end{tabular}

\begin{tabular}{lll}
\hline $\begin{array}{l}\text { Kemampuan membaca gambar dan } \\
\text { atau simbol }\end{array}$ & 6 & 35 \\
$\begin{array}{l}\text { Keserasian bentuk dengan yang } \\
\text { diharapkan dan atau ukuran yang }\end{array}$ & 9 & 65 \\
telah ditentukan & & \\
Rata-rata persentase ketuntasan & & 53 \\
\hline
\end{tabular}

\section{Siklus II}

Tahap perencanaan pada penelitian tindakan kelas pada siklus 2 dilakukan langkah-langkah penyiapan media pembelajaran, melakukan validasi media, menyusun rencana pelaksanaan pembelajaran, dan mengkonstruksi instrumen penilaian. Penelitian tindakan kelas siklus II dilakukan selama 2 kali pertemuan. Pertemuan yang dilaksanakan membahas materi mekanisme peredaran darah pada manusia (mekanisme peredaran darah), dan materi gangguan dan penyakit pada sistem peredaran darah manusia (gangguan, penyakit dan kelainan pada sistem peredaran darah manusia serta cara mengatasinya).

Penerapan media animasi memberikan interaksi antar siswa dan memberikan dampak terhadap cara siswa menyampaikan gagasannya. Media pembelajaran sebenarnya memiliki peluang dalam menciptakan ruang terhadap penyaluran ide, penyajian konsep materi dan interaksi dengan lingkungan belajar (Spyrtou, Hatzikraniotis, \& Kariotoglou, 2009). Pada siklus 2 terlihat hasil belajar siswa meningkat seperti yang terlihat pada tabel 5 dengan persentase rata-rata hasil belajar kognitif siswa sebesar $82,3 \%$.

Tabel 5. Hasil Belajar Kognitif Siklus II

\begin{tabular}{lc}
\hline \multicolumn{1}{c}{ Deskripsi Hasil Belajar Kognitif } & Siklus II \\
\hline Nilai rata-rata & 79,7 \\
Nilai maksimal & 95 \\
Nilai minimal & 6 \\
Standar deviasi & 8,56 \\
Persentase ketuntasan belajar & $82,3 \%$ \\
Persentase ketidaktuntasan belajar & $17,7 \%$ \\
\hline
\end{tabular}

Hasil yang didapatkan pada aspek afektif siklus kedua berdasarkan dari indikator keberhasilan dianggap sudah berhasil.Hal ini terlihat berdasarkan indikator keberhasilan pada aspek afektif yaitu sebesar $78 \%$.

Tabel 6. Data Afektif Siswa Siklus II

\begin{tabular}{lcc}
\hline \multicolumn{1}{c}{ Deskripsi Afektif Siswa } & Jumlah siswa & $\begin{array}{c}\text { Persentase } \\
(\%)\end{array}$ \\
\hline Disiplin & 15 & 88 \\
Bertanggung jawab & 12 & 71 \\
Teliti & 11 & 65 \\
Menghargai & 15 & 88 \\
Bekerja sama & 13 & 76 \\
Rata-rata persentase ketuntasan & & 78 \\
\hline
\end{tabular}

Penggunaan media animasi berbasis macromedia flash memberikan dampak yang positif terhadap aspek psikomotorik. Media animasi yang digunakan pada materi sistem peredaran darah menarik perhatian siswa sehingga siswa dapat memproses informasi dengan mudah. Pada saat pembelajaran siswa terlihat antusias dan cukup aktif 
dalam bertanya. Jika siswa dapat menyerap informasi dengan mudah, maka akan memaksimalkan banyaknya informasi yang diterima dan dipahami melalui pembelajaran macromedia flash (Gustina et al., 2016).

Tabel 7. Data Hasil Psikomotorik Siswa Siklus II

\begin{tabular}{lcc}
\hline \multicolumn{1}{c}{ Data Hasil Psikomotorik } & $\begin{array}{c}\text { Jumlah } \\
\text { siswa }\end{array}$ & $\begin{array}{c}\text { Persentase } \\
(\%)\end{array}$ \\
\hline $\begin{array}{l}\text { Kemampuan menggunakan alat } \\
\text { dan sikap kerja }\end{array}$ & 14 & 68 \\
$\begin{array}{l}\text { Kemampuan membaca gambar } \\
\text { dan atau simbol }\end{array}$ & 12 & 71 \\
$\begin{array}{l}\text { Keserasian bentuk dengan yang } \\
\text { diharapkan dan atau ukuran yang }\end{array}$ & 12 & 71 \\
$\begin{array}{l}\text { telah ditentukan } \\
\text { Rata-rata ketuntasan }\end{array}$ & & \\
\hline
\end{tabular}

Berdasarkan perolehan nilai ulangan harian kelas VII pada pra siklus dengan pencapaian siswa tuntas sebesar 25\% dengan nilai KKM 75, hasil belajar kognitif siswa mengalami peningkatan pada siklus I. Perolehan persentase ketuntasan belajar siswa pada siklus I dengan persentase $52.9 \%$. Selanjutnya hasil belajar kognitif juga mengalami kenaikan pada siklus II menjadi 82.3\%. Kenaikan persentase ketuntasan siswa dengan rata-rata 53,4\% menunjukkan bahwa terjadi perubahan dan peningkatan hasil belajar kognitif siswa dari pra siklus, siklus I dan siklus II. Peningkatan persentasi ketuntasan belajar siswa pada aspek kognitif dari pra siklus, siklus I ke siklus II tidak terlepas dari upaya perbaikan pengajaran guru melalui penggunaan media animasi berbasis macromedia flash. Guru berusaha melakukan pendekatan secara individu agar siswa dapat memahami materi. Penggunaan media animasi berbasis macromedia memberikan hasil yang cukup memuaskan melalui peningkatan hasil belajar. Temuan yang sama juga telah menunjukkan bahwa penggunaan media animasi merupakan salah satu faktor penting dalam meningkatkan hasil belajar (Saripudin et al., 2018; Kusuma et al., 2015).

Berdasarkan hasil belajar kognitif siswa, sebenarnya kemampuan akademik siswa masih pada kategori baik. Hal ini terlihat dari rata-rata nilai siswa yaitu 79,7 (tabel 5). Kemampuan akademik siswa yang meningkat di atas ratarata menunjukkan bhawa sswa dapat menerima dan memahami materi sistem peredaran darah dengan baik melalui media animasi. Meskipun ada beberapa siswa yang membutuhkan bantuan dan bimbingan langsung dari guru untuk dapat memahami materi. Media animasi dapat memberikan dampak yang baik bagi siswa dalam pembelajarannya khususnya dalam pemahaman siswa terhadap materi. (Sari, 2013). Selain itu, media animasi dapat memberikan kepuasan tersendiri bagi guru dalam mengajarkan materi yang bersifat abstrak dan memberikan kesempatan kepada siswa untuk berproses dalam belajar (Rotbain et al., 2008).

Antusias siswa dalam pelaksanaan pembelajaran terlihat dari berbagai pertanyaan dan tanggapan siswa pada saat pelaksanaan pembelajaran berlangsung. Kemenarikan media animasi yang disajikan membangkitkan rasa ingin tahu siswa. Khususnya aspek visual yang disajikan dalam media animasi dapat membantu siswa dalam memahami materi menjadi lebih mudah. Perancangan media pembelajaran berbasis macromedia flash pada materi sistem peredaran darah manusia mendukung proses pengajaran guru karena dapat memberikan visualisasi yang sesuai dengan asli melalui penyampaian audio visual kepada siswa. Penekanan aspek visual dapat mengoptimalkan daya ingat dan pemahaman siswa sehingga materi dapat tersampaukan dengan baik kepada siswa (Dinata, 2016). Penggunaan media animasi memberikan penekanan khusus pada proses ilustrasi materi sehingga membantu siswa dalam memahami materi melalui pengamatan konkrit. Implementasi media pembelajaran berbasis IT dalam meningkatkan mutu pembelajaran juga harus diimbangi dengan pemahaman yang diperoleh baik dalam penggunaan dan pemanfaatan media berbasis teknologi informasi tersebut (Sidiq, 2016; Ismunandar, 2017).

Hasil belajar siswa pada aspek sikap siklus I memiliki nilai rata-rata yaitu 55\%.Perolehan hasil aspek afektif pada siklus I masih belum mencapai ketuntasan yang diharapkan yaitu sebesar $70 \%$. Upaya yang dilakukan oleh guru dan kolaborator adalah dengan melakukan modifikasi pelaksanaan pembelajaran siklus II pada skenario pembelajaran. Guru melakukan integrasi sikap pada setiap materi yang diajarkan. Kegiatan pembelajaran melalui kelompok dengan jumlah kelompok yang semula beranggotakan 5-6 siswa, diubah menjadi 2-3 siswa. Hal ini bertujuan agar siswa dapat memiliki tanggung jawab yang lebih besar pada masing-masing kelompoknya. Selain itu, pola kerja sama dalam kelompok dapat lebih dilakukan. Siswa dapat terlibat aktif jika jumlah anggota kelompok tidak terlalu besar.

Pelaksanan kegiatan praktikum pada siklus II juga menuntut siswa agar disiplin dalam penggunaan waktu dan teliti dalam pengumpulan data hasil praktikum. Hasilnya, pada siklus II, hasil belajar siswa aspek afektif mencapai hasil sebesar $78 \%$. Masing-masing indikator sikap yaitu disiplin, bertanggung jawab, telit, menghargai dan bekerja sama mengalami peningkatan dari siklus I. Hal ini membuktikan bahwa integrasi sikap dalam pelaksanaan media animasi membutuhkan suatu pengelolaan kelas dan pendekatan individu sehingga karakter dan sikap siswa dapat ditumbuhkembangkan. Media macromedia flash dapat dikonstruksi sesuai dengan karakter siswa serta dapat memberikan dampak positif pada perilaku siswa di kelas (Muhtarom, 2017).

Aspek psikomotorik pada pembelajaran sistem peredaran darah diimplementasikan melalui pelaksanaan kegiatan praktikum identifikasi benda-benda darah, uji golongan darah dan rhesus. Berdasarkan perolehan ratarata hasil belajar pada aspek psikomotorik siswa pada siklus I yaitu 53\% mengalami peningkatan hingga $75 \%$ pada siklus II. Ketuntasan ang diinginkan pada aspek psikomotorik yaitu $\geq 75 \%$. Hal ini menunjukkan bahwa kemampuan siswa dalam aspek psikomotorik dapat berkembang melalui proses pembelajaran secara teori melalui media animasi dan aktivitas yang dibangun dalam kegiatan praktikum. Perubahan yang ditunjukkan dari siklus II merupakan upaya perbaikan yang dilakukan oleh guru dari penyajian media animasi yang dikombinasikan dengan kegiatan praktikum di laboratorium. Berdasarkan analisis data pada aspek psikomotorik ditemukan bahwa 
terdapat perubahan cara pandang siswa melalui mental dan penempatan diri siswa sebagai seorang saintis. Mental yang terbentuk terlihat dari rasa ingin tahu dan sikap kerja siswa dalam kegiatan pembelajaran. Sejalan dengan temuan penelitian Barak \& Dori (2011), yang menyatakan bahwa penggunaan media animasi dapat berkontribusi dalam mengkonstruksi mental siswa sebagai mental seorang saintis melalui panduan-panduan yang difasilitasi melalui media animasi.

Penguatan dari aspek materi diberikan melalui kegiatan praktikum. Berdasarkan indikator psikomotorik yang diukur, siswa mengalami peningkatan dari aspek kemampuan menggunakan alat dan sikap kerja hingga $68 \%$, kemampuan membaca gambar dan atau symbol $71 \%$, dan keserasian bentuk dengan yang diharapkan dan atau ukuran yang telah ditentukan 71\%. Hal ini menunjukkan bahwa pelaksanaan pembelajaran media animasi memberikan pemahaman yang optimal bagi siswa sehingga mendukung siswa dalam aspek psikomotorik. Interaksi yang dibangun melalui media animasi memberikan ruang kepada siswa untuk dapat lebih aktif dalam kelompoknya melalui aktivitas diskusi (Budiono, 2018).

\section{SIMPULAN}

Hasil belajar siswa pada aspek sikap siklus I memiliki nilai rata-rata yaitu 55\%.Perolehan hasil aspek afektif pada siklus I masih belum mencapai ketuntasan yang diharapkan yaitu sebesar $70 \%$. Upaya yang dilakukan oleh guru dan kolaborator adalah dengan melakukan modifikasi pelaksanaan pembelajaran siklus II pada skenario pembelajaran. Sementarapencapaian aspek psikomotorik yang diukur berdasarkan indikator mengalami peningkatan dari aspek kemampuan menggunakan alat dan sikap kerja hingga 68\%, kemampuan membaca gambar dan atau simbol 71\%, dan keserasian bentuk dengan yang diharapkan dan atau ukuran yang telah ditentukan 71\%.

\section{REFERENSI}

Agustina, M., Sesunan, F., \& Ertikanto, C. (2018). Pengaruh Implementasi Media Pembelajaran Interaktif Berbasis Macromedia Flash terhadap Hasil Belajar pada Materi Hukum Newton tentang Gravitasi. Jurnal Pembelajaran Fisika, 5(5).

Anwar, A. K., Karmana, I. W., \& Harisanti, M. (2017). Jurnal Ilmiah Pendidikan Biologi "Bioscientist" Vol. 5 No.2, ISSN 2338-5006. Jurnal Ilmiah Pendidikan Biologi "Bioscientist," 5(2), 70-81.

Barak, M., \& Dori, Y. J. (2011). Science Education in Primary Schools: Is an Animation Worth a Thousand Pictures? Journal of Science Education and Technology, 20(5), 608-620. https:/ /doi.org/10.1007/s10956-011-9315-2

Budiono. (2018). Use of Learning CD Media to Improve Student Motivation and Mathematics Learning Outcomes, 8(2), 101-110. https://doi.org/http://dx.doi.org/10.30998/format if.v8i2.2459 Use

Dinata, S. (2016). Penggunaan Gambar Fotografi untuk Meningkatkan Hasil Belajar Siswa Pada Materi
Kaitan Aktivitas Ekonomi dengan Sumber Daya Alam, 15(2).

Gustina, G., Abu, St.H.N., \& Hamsyah, E. F. (2016). Pengaruh Penggunaan Media Pembelajaran Berbasis Macromedia Flash 8 Terhadap Motivasi dan Hasil Belajar Kognitif Siswa Kelas VII SMPN 18 Makassar Studi pada Materi Pokok Asam , Basa dan Garam. Chemica, 17(2), 12-18.

Ismunandar, N. (2017). Penerapan media pembelajaran berbasis macromedia flash 8.0 untuk meningkatkan motivasi dan hasil belajar pada kompetensi sistem pengisian konvensional siswa kelas VII semester genap teknik kendaraan ringan di SMK Negeri 1 Nglipar tahun 2016/2017. Universitas Negeri Yogyakarta. Retrieved from http://eprints.uny.ac.id/49093/1/13504244013_Nu rul Ismunandar_TAS.pdf

Kusuma, P. S., Chamisijatin, L., Nur, D., \& Widodo. (2015). Peran Biologi dan Pendidikan Biologi dalam Menyiapkan Generasi Unggul dan Berdaya Saing Global. In Prosiding Seminar Nasional Pendidikan Biologi 2015 FKIP Universitas Muhammadiyah Malang (pp. 386-392). Prodi Pendidikan Biologi FKIP Universitas Muhammadiyah Malang.

Mahdjoubi, L., \& A-Rahman, M. A. (2012). Effects of multimedia characteristics on novice CAD learners practice performance. Architectural Engineering and Design Management, 8(3), 214-225. https://doi.org/10.1080/17452007.2012.683244

Mnguni, L. E. (2014). The theoretical cognitive process of visualization for science education. SpringerPlus, 3(1), 1-9. https://doi.org/10.1186/2193-1801-3184

Muehrer, R., Jenson, J., \& Friedberg, J. (2012). Challenges and opportunities: using a science-based video game in secondary school settings. Cult Stud of Sci Educ, 7, 783-805. https://doi.org/10.1007/s11422012-9409-z

Muhtarom. (2017). Penerapan Media Audio Visual Macromedia Flash dan Power Point untuk Meningkatkan Hasil Belajar Matematika Sekolah Dasar. Widyagogik, 4(2), 145-154.

Paidi. (2010). Penelitian Tindakan Kelas (Disain Tindakan, Monitoring, dan Analisis Data). Yogyakarta.

Rotbain, Y., Marbach-Ad, G., \& Stavy, R. (2008). Using a computer animation to teach high school molecular biology. Journal of Science Education and Technology, 17(1), 49-58. https://doi.org/10.1007/s10956-007-9080-4

Saminanto. (2010). Ayo Praktik PTK. Semarang: Rasail Media Group.

Sari, I. N. S. S. A. (2013). Pengembangan Multimedia Pembelajaran Berbasis Macromedia Flash Sebagai. Jurnal Pendidikan Kimia (JPK), 2(3), 152-157.

Saripudin, E., Sari, I. J., \& Mukhtar, M. (2018). Using Macro Flash Animation Media on Motion Material to Improve Learning Achievement for Learning Science in Junior High School. Jurnal Penelitian Dan Pembelajaran IPA, 4(1), 68. https://doi.org/10.30870/jppi.v4i1.3316

Sidiq, Z. (2016). Pemanfaatan Media Pembelajaran 
Berbasis Teknologi Informasi dalam Pembelajaran, 15(1), 98-108. https://doi.org/10.1145/223904.223929

Spyrtou, A., Hatzikraniotis, E., \& Kariotoglou, P. (2009). Educational software for improving learning aspects of Newton's Third Law for student teachers. Education and Information Technologies, 14(2), 163-187. https://doi.org/10.1007/s10639-0099087-y

Sukiyasa, K. (2013). Pengaruh Media Animasi Terhadap Hasil Belajar Dan Motivasi Belajar Siswa Materi Sistem Kelistrikan Otomotif. Jurnal Pendidikan Vokasi Jurnal Pendidikan Vokasi, 3(1), 129. https://doi.org/http://dx.doi.org/10.21831/jpv.v3i 1.1588
Surani. (2015). Pemanfaatan media pembelajaran flash pada materi lensa untuk meningkatkan hasil belajar siswa kelas VII MTS Miftahuth Tholibin Mranggen tahun pelajaran 2014/2015. Universitas Islam Negeri Walisongo Semarang.

Trindade, J. F. e. (2005). Improving Physics learning with virtual environments: an example on the phases of water. Interactive Educational Multimedia, 11(11), 212-226.

Wulandari, E. (2017). Penerapan multimedia interaktif berbasis macromedia flash 8 terhadap keaktifan dan hasil belajar biologi materi sistem saraf manusia pada siswa kelas XI SMA PPMI Assalaam Sukoharjo tahun pelajaran 2016/2017. Universitas Muhammadiyah Surakarta. 